

\section{I0lonnu skuripton}




\title{
Ullounu skiripten
}

Jurnal Manassa

Volume 8, Nomor 2, 2018

\author{
PIMPINAN REDAKSI
}

Oman Fathurahman

\begin{abstract}
DEWAN PENYUNTING INTERNASIONAL
Achadiati Ikram, Al Azhar, Annabel Teh Gallop, Dick van der Meij, Ding Choo Ming, Edwin Wieringa, Henri Chambert-Loir, Jan van der Putten, Mujizah, Lili Manus, Munawar Holil, Nabilah Lubis, Roger Tol, Siti Chamamah Soeratno, Sudibyo,

Titik Pudjiastuti, Tjiptaningrum Fuad Hasan, Yumi Sugahara, Willem van der Molen
\end{abstract}

\section{REDAKTUR PELAKSANA \\ Muhammad Nida' Fadlan \\ Aditia Gunawan}

PENYUNTING

Ali Akbar, Asep Saefullah, Agus Iswanto, Dewaki Kramadibrata, M. Adib Misbachul Islam, Priscila Fitriasih Limbong, Yulianetta

\author{
ASISTEN PENYUNTING \\ Abdullah Maulani \\ DESAIN SAMPUL \\ Muhammad Nida' Fadlan
}

\begin{abstract}
ALAMAT REDAKSI
Sekretariat Masyarakat Pernaskahan Nusantara (MANASSA)

Gedung VIII, Lantai 1, Fakultas IImu Pengetahuan Budaya, Universitas Indonesia, Kampus UI Depok, 16424

Website. http://journal.perpusnas.go.id/index.php/manuskripta Email.jmanuskripta@gmail.com
\end{abstract}

MANUSKRIPTA (P-ISSN: 2252-5343; E-ISSN: 2355-7605) adalah jurnal ilmiah yang dikelola oleh Masyarakat Pernaskahan Nusantara (Manassa), asosiasi profesi pertama dan satu-satunya di Indonesia yang memperhatikan pengkajian dan pelestarian naskah Nusantara. Jurnal ini dimaksudkan sebagai media pembahasan ilmiah dan penyebarluasan hasil penelitian di bidang filologi, kodikologi, dan paleografi. Terbit dua kali dalam setahun. 


\section{Daftar Isi}

\section{Artikel}

1 Doni Wahidul Akbar, Titin Nurhayati Ma'mun

Musa Kang Kapisan Kaarangan Purwaning Dumadi:

Kajian Teologi Penciptaan Alam dan Manusia

$23 \quad$ Nurhata

Revitalisasi Kearifan Lokal Naskah-naskah Primbon

Koleksi Masyarakat Indramayu

43 Agus Iswanto

Praktik Literasi Agama pada Masyarakat Indonesia

Tempo Dulu: Tinjauan Awal atas Naskah-naskah Cirebon

67 Binarung Mahatamajangga

Kisah Kisah Raja "Kafir" Nusirwan

dalam Naskah Ki Sarahmadu Brajamakutha:

Kajian terhadap Repertoire Penyusunnya

89 Trisna Kumala Satya Dewi, Heru Supriyadi, Sholeh Dasuki Kearifan Lokal Mitos Pertanian Dewi Sri

dalam Naskah Jawa dan Aktualisasinya

sebagai Perekat Kesatuan Bangsa

109 Riski Wulandari

Intertekstual antara Syair Nabi Allah Ayub

dengan Hikayat Nabi Ayub Dimurkai Allah

123 Ellya Roza

Konsep Kesehatan Raja Haji Daud

dalam Naskah Risalah Asal IImu Tabib 
149 Muhammad Bindaniji

Nalar Teologi Sunnī al-Rānīrī

dalam Naskah Durr al-Farā'id: Kajian Historis-Teologis

169 Nining Sudiar, Rosman H, dan Hadira Latiar

Peta Naskah Kuno Kabupaten Kampar Provinsi Riau

183 Tedi Permadi, Emmy Ratna Gumilang Damiasih, Euis Kurniasih Penyelamatan Naskah-naskah Karya Pangeran Madrais dengan Teknik Digitalisasi

\section{Review Buku}

195 Abdullah Maulani

Manuskrip dan Jawaban atas Tantangan di Era Milenial 


\title{
Konsep Kesehatan Raja Haji Daud dalam Naskah Risalah Asal IImu Tabib
}

\begin{abstract}
This paper aims to analyze the contents of the text of the Risalah Asal IImu Tabib (RAIT) collection of the Sang Nila Utama Museum in Pekanbaru. This text is a copy of the manuscript of Raja Haji Daud bin Engku Haji Ahmad bin Almarhum Fi Sabilillah. The text is one proof that the people of the past have a high intellectual level. This paper is a preliminary study to uncover the content of the text using the philology method. At the end of the study it was found that this text contained a message to humans to maintain the balance of the four elements in their bodies, namely wind, fire, water and land. The four elements must be balanced because if there is a deficiency or excess one of them, then the disease will come into the human body. There are four characteristics of diseases that attack humans, namely: (1) ash-shafrawi, which is the pain of mirrat, the nature is hot and dry because of its element of fire and its place around bile; (2) as-sudawi, which is ill, it is cool dry because of the element of the soil and its place in the spleen; (3) al-balghomi, a slimy disease, the nature is wet because of the element of water and its place in the lungs; (4) ad-damawi, which is blood pain, the nature is hot and wet because of the element of the wind and its place in the heart.
\end{abstract}

Keywords: Raja Haji Daud, Medicine, Risalah Asal IImu Tabib, Health, Pekanbaru

\begin{abstract}
Abstrak: Tulisan ini bertujuan untuk menganalisis kandungan teks Risalah Asal Ilmu Tabib (RAIT) koleksi Museum Sang Nila Utama Pekanbaru. Naskah ini merupakan salinan dari naskah Raja Haji Daud bin Engku Haji Ahmad bin Almarhum Fi Sabilillah. Naskah tersebut merupakan salah satu bukti bahwa masyarakat masa lalu memiliki tingkat intelektual yang tinggi. Tulisan ini merupakan kajian awal untuk mengungkap kandungan teksnya dengan menggunakan metode filologi. Di akhir kajian ditemukan bahwa naskah ini mengandung pesan kepada manusia untuk menjaga keseimbangan empat unsur yang ada dalam tubuhnya, yakni angin, api, air dan tanah. Keempat unsur tersebut harus seimbang karena jika terjadi kekurangan atau kelebihan salah satunya, maka penyakit akan datang ke dalam tubuh manusia. Ada empat sifat penyakit yang menyerang manusia, yaitu: (1) ash-shafrawi, yakni sakit mirrat, tabiatnya panas dan kering karena unsurnya api dan tempatnya sekitar empedu; (2) as-sudawi, yakni sakit pitam, tabiatnya sejuk kering karena unsurnya tanah dan tempatnya di limpa; (3) al-balghomi, penyakit yang berlendir, tabiatnya basah karena unsurnya air dan tempatnya di paru-paru; (4) ad-damawi, yakni sakit darah, tabiatnya panas dan basah karena unsurnya angin dan tempatnya di hati.
\end{abstract}

Kata Kunci: Raja Haji Daud, Pengobatan, Risalah Asal Ilmu Tabib, Kesehatan, Pekanbaru. 
Naskah merupakan warisan budaya dan warisan intelektual yang memiliki sejumlah kandungan isi dari berbagai aspek. Pada posisi ini warisan tersebut menjadi penting untuk diteliti karena dapat menjadi sumber pengetahuan masyarakat sekarang. Dengan demikian peninggalan kebudayaan berupa naskah merupakan dokumen bangsa yang paling menarik untuk diteliti karena memiliki kelebihan yaitu dapat memberi informasi yang lebih luas dibanding dengan peninggalan kebudayaan dalam bentuk lainnya. ${ }^{1}$

Meskipun sudah dilakukan inventarisasi naskah oleh berbagai institusi, namun jumlah naskah tidak bisa ditetapkan secara pasti karena penelusuran naskah masih berlangsung hingga saat ini di berbagai daerah. ${ }^{2}$ Selain itu juga disebabkan faktor lain, misalnya karena (1) naskah-naskah itu telah banyak yang berpindah tangan, kadang-kadang sampai lebih dari dua kali dari pemegang naskah semula; (2) secara tidak terduga sering dijumpai naskah pada tempattempat tertentu yang sebelumnya tidak diperoleh keterangan tentang adanya naskah tersebut di tempat itu; (3) naskah-naskah itu banyak yang tidak diperkenankan oleh pemilik atau pemegangnya karena merupakan barang warisan dari orang tua atau leluhurnya atau karena ada sebab lain. ${ }^{3}$

Naskah yang tidak bisa dihitung tersebut tersimpan di berbagai tempat penyimpanan naskah. Akan tetapi, menurut Lubis, minat penelitian terhadap naskah masih rendah. ${ }^{4}$ Terlebih lagi terhadap naskah pengobatan tradisional, karena para peneliti umumnya tidak

\footnotetext{
${ }^{1}$ Musa, Mohamad Zain dan Nik Hassan Shuhaimi Nik Abdul Rahman, "Peranan Budaya dalam Mempromosikan Keharmonisan di Asia Tenggara," dalam Jurnal Terjemahan Alam dan Tamadun Melayu, Jilid 1, No. 2, (183-189), Bangi: ATMA UKM, 2010, h.183. Mu'jizah (editor), Dinamika Pernaskahan Nusantara, Jakarta: Manassa dan Yanassa, 2017, h. 3. Lihat juga Soebadio, Filologi, makalah pada seminar Prasarana Daerah Bali-Sunda-Jawa, Yogyakarta, 1975.

2 Ellya Roza, Naskah Melayu, Pekanbaru: Yayasan Pusaka, 2011, h. 69. Mulyadi "Kodikologi Melayu di Indonesia", Jurnal Lembar Sastra, No. 24, (Depok: FASA UI, 1994); Chambert-Loir dan Oman Faturrahman, Panduan Koleksi Naskah-naskah Nusantara, Jakarta: Yayasan Obor Indonesia, 1999.

${ }^{3}$ Ellya Roza, Naskah Melayu, h. 72.

${ }^{4}$ Lubis, "Kajian Filologi di Indonesia”, Jurnal Lektur Keagamaan, Vol. 3, No.1, (71-89), Jakarta: Puslitbang Lektur Keagamaan Depag RI, 2005, h.71; Samrudin Nasution, "Kajian Naskah Kitab Sairu al-Salikin libabi Ihya'Ulumuddin Karya Syekh Ali ibn Abdurrahman alKalantani," Jurnal Sosial Budaya, Vol. 11, No. 1(70-90), Pekanbaru: UIN Suska Riau, 2014.
} 
tertarik akan naskah tersebut. Padahal kandungan isinya memuat solusi dan alternatif pilihan yang dapat digunakan masyarakat sekarang untuk mengobati dan mencegah penyakit. Bahkan dapat meringankan beban ekonomi masyarakat. ${ }^{5}$ Secara fakta dan kenyataan, pengobatan tradisi telah diakui mempunyai posisi tersendiri dalam pengobatan modern secara keseluruhan. Bahan obat yang digunakan dalam pengobatan tradisional mempunyai khasiat tertentu bagi manusia. ${ }^{6}$

Kandungan teks masa lampau tidak terbatas pada satu tema saja melainkan terdapat berbagai macam kandungannya. Salah satunya adalah naskah yang memiliki kandungan teks yang berkaitan dengan penyakit manusia. Penyakit akan menyerang tubuh manusia akibat tidak adanya keseimbangan unsur-unsur yang terkandung di dalam tubuhnya, yang terdiri atas empat unsur, yaitu kandungan api, air, angin dan tanah. Keempat jenis tersebut harus seimbang adanya. Artinya tubuh manusia tidak didominasi oleh satu jenis unsur saja. Sebagaimana pepatah mengatakan bahwa al-'aqlu as-salìm fi al-jism as-salïm, yang mengandung makna "akal pikiran yang sehat terdapat dalam tubuh yang sehat". Oleh karena itu, masalah kesehatan, terutama menghindari penyakit, merupakan hal yang urgen untuk diperhatikan oleh manusia.

Salah satu teks yang menjelaskan tentang pencegarah penyakit tersebut adalah Risalah Asal IImu Tabib (selanjutnya disingkat RAIT) dari Alam Melayu. Analisis kandungan teks RAIT dapat dilakukan dari berbagai aspek bidang ilmu; bahkan dapat dikaitkan dengan Al-Qur'an dan hadis karena RAIT ditulis pada masa agama Islam menjadi dasar keyakinan masyarakat asalnya di Alam Melayu. Dengan menghubungkan RAIT dengan Islam, maka dapat dikatakan integrasi

${ }^{5}$ Ellya Roza, "Ramuan Herbal Non Instan Dalam Naskah Kitab Tib sebagai Alternatif Pengobatan", Jurnal Sosial Budaya: Media Komunikasi IImu-ilmu Sosial dan Budaya, Vol. 11, No. 1, Januari-Juni 2014 (1-18). h.1. Zain, "Sains dan Teknologi Melayu sebelum Penjajahan Eropah", Jurnal Melayu, Jilid 1, No. 2, (157-204), Kuala Lumpur: Dewan Bahasa dan Pustaka, 2003, h.157. Mariyah M.S., Kumpulan Mujarrobat Lengkap, Surabaya: Mahkota; Labib MZ. dan Ahnan, Primbon Mujarrobat Kubra, Surabaya: Bintang Usaha Jaya.

6 Moh. Taib Osman, "Kitab Ubat-ubat Melayu", Rogayah A. Hamid dan Mariam Salim, Kepustakaan IImu Tradisional, Kuala Lumpur: Dewan Bahasa dan Pustaka, 2006, h. 2. Syaifullah, Pengaruh Ruqyah Syar'iyyah dalam Pengobatan Fisik di Propinsi Riau, Hasil Penelitian, Pekanbaru: LPPM UIN Suska Riau, 2016; Mohd. Affendi Mohd. Shafri dan Intan Azura Shahdan, Malay Medical Manuscripts (Heritge From The Garden of Healing), Kuantan: The Islamic Manuscripts Assosiation, 2017. 
ilmu ${ }^{7}$ telah terjadi. Hal ini bersesuaian dengan pandangan M. Amin Abdullah bahwa integrasi merupakan suatu paradigma dan pendekatan sebagai upaya mempertemukan ilmu agama (Islam) dengan ilmuilmu umum (Abdullah, 2007: 5). Salah satunya adalah naskah Melayu, termasuk naskah RAIT, yang berhubungan erat dengan kajian bahasa dan sastra karena ditulis dengan menggunakan aksara Arab Melayu.

Menganalisis kandungan teks RAIT akan memberikan manfaat kepada berbagai pihak antara lain (1) pemerintah, karena dengan penelitian ini berarti terlaksana sebuah program tentang aspek pelestarian dan peninggalan budaya masyarakat; (2) masyarakat, karena hasil penelitian ini dapat diketahui bahkan bisa diamalkan oleh masyarakat dalam mengatasi persoalan hidup yang berkaitan dengan kesehatan; (3) ilmuwan, karena kegiatan penelitian naskah dapat menjadi bahan dan sumber penelitian pula bagi ilmuwan lainnya; (4) akademisi, karena dengan meneliti naskah RAIT dapat memberikan informasi mengenai hal-hal yang berkaitan dengan penyakit yang membuat manusia sehat secara alamiah.

Berdasarkan pengamatan terhadap hasil pendataan Ekajdati (2000) naskah dalam Direktori Edisi Naskah Nusantara, naskah RAIT yang merupakan karya Raja Haji Daud bin Raja Haji Ahmad bin Raja Haji Fi Sabilillah tidak tercantum di dalamnya. Artinya, naskah yang menjadi bahan tulisan ini belum pernah diteliti. Hanya saja naskah ini pernah di transliterasikan dan berikutnya dicetak menjadi sebuah buku (Roza 2010). Selanjutnya, mengenai tulisan yang berkaitan dengan pengobatan Melayu telah dirangkum oleh Rogayah A. Hamid dan Mariam Salim (2006). Namun, RAIT tidak diikutsertakan dalam rangkuman tersebut. Pada tahun 2006 , Harun Mat Piah (2006) telah meneliti naskah beberapa syair Melayu, namun RAIT juga tidak ditemukan dalam kajiannya. Selanjutnya Ab. Razak Ab. Karim (2002) menulis dengan judul "Kepelbagaian Jenis Penyakit dan Bahan-bahan Perubatan," juga berbeda dengan kajian ini.

Dari segi metodologi, tulisan ini merupakan kajian terhadap

\footnotetext{
${ }^{7}$ Kajian mengenai integrasi keilmuan dewasa ini sangat marak dibicarakan oleh kalangan intelektual muslim, antara lain Naquib Al-Attas dalam buku yang berjudul Konsep Pendidikan dalam Islam, terj. Haidar Bagir, (Bandung: Mizan, 1984); M. Amin Abdullah dalam buku Islamic Studies dalam Paradigma Integrasi-Interkoneksi, Cet. I, Yogyakarta: SUKA Press, 2007; dalam buku Studi Agama Normativitas atau Historisitas? (Yogyakarta: Pustaka Pelajar, 2002).
} 
peninggalan budaya berupa naskah yang menitikberatkan pada aspek filologi, ${ }^{8}$ (taḥqiq an-nușūṣ) dengan menggunakan metode deskriptif kualitatif (Nazir, 2000: 63; Hartono, 2011; Vredenbergt, 2002: 4-9). Metode kualitatif yang dimaksud adalah upaya memahami sedemikian rupa dengan tidak memerlukan kuantifikasi. Artinya dalam kajian naskah ini dilakukan pendekatan kualitatif yang sering dikaitkan dengan analisis dan interpretasi (Maloeng, 1997: 4-5; Muhadjir, 2000) yang akhirnya memfokuskan pada content analysis (Endaswara, 2006; Sugiyono, 2013). Dalam usaha mencari naskah tidak dilakukan penelusuran kepada masyarakat tetapi melalui katalogus naskah yang terdapat di berbagai perpustakaan dan museum. Tahapan tersebut merupakan kerja filologi, yakni inventarisasi naskah (Djamaris, 2000: 11) dilakukan terhadap naskah RAIT. Naskah ini kemudian dideskripsikan untuk mengetahui kondisi fisik naskah, dan dilanjutkan ke tahap berikutnya, yakni menganalisis kandungan teksnya.

\section{Deskripsi Naskah Risalah Asal IImu Tabib}

Penamaan naskah berdasarkan pada kalimat yang tertulis pada halaman pertama alenia kedua, yakni adapun kemudian daripada ayat inilah suatu risalah pada menyatakan mengetahui asal ilmu tabib yaitu mengetahui manusia daripada panas atau sejuk. Dengan adanya keterangan yang tertulis di dalam naskah, dengan demikian, penulis menjadikan judul naskahnya Risalah Asal IImu Tabib atau disingkat RAIT.

Naskah RAIT merupakan koleksi Museum Sang Nila Utama Pekanbaru yang beralamat di jalan Jenderal Sudirman Pekanbaru. Penulis hanya mendapatkan copy naskah di museum tersebut sedangkan naskah aslinya tidak ditemukan. Fotocopy naskah diberikan kepada penulis oleh bapak Yoserizal, Kepala Dinas Kebudayaan Provinsi Riau sekarang, yang ketika itu sebagai pegawai di Museum Sang Nila Utama. la memberikan

${ }^{8}$ Beberapa teori tentang filologi dibahas oleh Hasan Muarif Ambary, "Kontribusi Filologi, Sejarah dan Arkeologi bagi Pengembangan Kebudayaan Indonesia", Jurnal Lektur Keagamaan, Vol. 3, No.1, (90-103), Jakarta: Puslitbang Lektur Keagamaan Depag RI, 2005, h. 91. Baroroh Baried, dkk, Pengantar Teori Filologi, Jakarta: Pusat Pembinaan dan Pengembangan Bahasa, 1983, h. 2; Pradotokusumo, Kakawin Gajah Mada: Sebuah Karya Sastra Abad ke-20 Suntingan Naskah Serta Telaah Struktur Tokoh dan Hubungan Antar Teks, Bandung: Binacipta,1986; Oman Fathurrahman, dkk, Filologi dan Islam Indonesia, Jakarta: Balitbang dan Diklat Keagamaan Depag RI, 2010; Oman Faturrahman, Filologi Plus: Metode dan Pendekatan, Paper pada Temu Peneliti Naskah Keagaman Puslitbang Lektur Keagamaan, (Bukittinggi: 7-10 Juli 2010). 
dalam rangka kegiatan transliterasi naskah ke aksara Latin karena naskah RAIT bertuliskan aksara Jawi (Arab-Melayu). Transliterasinya telah penulis lakukan, dan pada masa berikutnya dicetak menjadi sebuah buku yang menjadi bagian koleksi museum Sang Nila Utama.9

Apabila memperhatikan keadaan naskah secara fisik dapat dikatakan baik karena lembaran naskah tidak ada yang rusak. Artinya tulisan naskah dapat dibaca. Ukuran teks tergolong kecil karena satu halamannya memuat 22 baris, yang dimulai dari halaman 2 sampai halaman 11 . Sedangkan pada halaman pertama terdapat 21 baris tulisan, halaman 12 terdiri dari 12 baris tulisan, dan halaman 13 terdapat 15 baris.

Keberadaan naskah di Museum Sang Nila Utama dapat dilihat pada catatan inventarisasi naskah. Dalam inventarisasi naskah terbaru pada tahun 2017, naskah Risalah Asal Ilmu Tabib tidak tercatat. Keberadaan naskah RAIT asli belum diketahui sampai sekarang. Akan tetapi, penulis masih menyimpan salinan naskahnya. Demikian juga buku hasil transliterasinya yang diberi judul Asal IImu Tabib, yang merupakan koleksi Museum Sang Nila Utama Pekanbaru, masih tersedia di museum tersebut.

\section{Sekelumit tentang Raja Haji Daud}

Berdasarkan kolofon yang tertulis dalam naskah pada halaman 13, diketahui bahwa naskah yang diteliti ini adalah naskah salinan dari naskah yang dikarang oleh Raja Haji Daud bin Raja Ahmad bin Raja Haji Fi Sabilillah. Penyalinan naskah selesai dilakukan pada tanggal 14 Muharram $1351 \mathrm{H}$. Mengenai siapakah yang menyalin naskah tidak ditulis di dalam kolofon sehingga penyalinnya tidak dapat diketahui dengan pasti. Diperkirakan penyalinnya tidak jauh dari lingkungan wilayah Kerajaan Melayu Riau Lingga. Untuk lebih jelasnya, transliterasi kolofon tersebut sebagai berikut:

Tamat kalam bilkhair a'la ad-dawām kepada 14 hari bulan Muharram malam Jum'at waktu jam pukul tujuh setengah dari hijrah 1351. Disalin dari naskah almarhum Raja Haji Daud bin Engku Haji Ahmad bin Almarhum Fi Sabilillah. ${ }^{10}$

9 Kegiatan dilakukan pada tahun 2010.

10 RAIT, h. 13. 
Raja Haji Daud merupakan keturunan ketiga dari Raja Haji Fi Sabilillah dan juga saudara Raja Ali Haji yang terkenal dengan gurindam 12-nya. Keturunan Raja Haji Fi Sabilillah menjadi pelaku utama dalam perkembangan tradisi tulis di Kerajaan Melayu Riau. Salah satunya adalah Raja Haji Daud yang telah menghasilkan banyak karya sastra, di antaranya adalah RAIT.

Kerajaan Melayu Riau selalu berubah-ubah namanya sesuai dengan letak istana sultan ketika memimpin kerajaannya. Kerajaan ini pernah dinamakan (1) Kerajaan Johor-Riau; (2) Kerajaan Johor-Riau-Pahang. Setelah tahun 1824 dinamakan dengan (3) Kerajaan Riau (tanpa Johor dan Pahang); (4) Kerajaan Lingga-Riau; (5) Kerajaan Riau-Lingga; (6) bahkan dinamakan juga dengan Kerajaan Riau (Yunus, 2002: 8). Namun secara resmi Riau Lingga digunakan sebagai nama kerajaan, setelah kerajaan itu berpisah dari kerajaan Johor dan Pahang pada tahun 1824 (Marks, 1959). Selanjutnya Netscher mengidentifikasikan bahwa penduduk yang mendiami Kerajaan Riau Lingga terdiri dari berbagai etnis, seperti Melayu, Bugis, Cina, Arab, India, dan bangsa Eropa. Akan tetapi, tidak disebutkan jumlah masing-masing pembagian berdasarkan etnis tersebut (Netsher, 1854: 108-270).

Ketika kekuasaan pemerintahan Riau-Lingga dijalankan oleh Deang Marewah, pengaruh Bugis makin besar sejak itu, dan sultan hanya sebagai lambang saja. Sultan Sulaiman menyadari adanya tekanan dari orang-orang Bugis lalu ia meminta bantuan kepada Belanda untuk mengusir orang Bugis. Akibat campur tangan Belanda, maka pertikaian antara Sultan Sulaiman dengan orang Bugis berlangsung lama. Namun, pada tanggal 1 Desember 1759, pertikaian berakhir setelah diadakan perdamaian antara Sultan Sulaiman dengan orang Bugis di mana kedudukan orang Bugis diakui kembali sebagai Yang Dipertuan Muda (Yunus, 2002: 9).

Meskipun dalam bidang ekonomi, politik, militer dan perdagangan mengalami kemerosotan dan kemunduran, namun di bidang intlektualisme dan kebudayaan terus berkembang. Menurut Helmiati (2007), hal ini ditandai dengan tradisi tulis menulis di kalangan istana sehingga tantangan zaman yang terjadi di masyarakat dapat teratasi. Selain itu, lahirnya para penulis di lingkungan istana membawa dampak positif di kalangan masyarakat yang sedang berkembang. Raja Ahmad 
lah orang pertama yang mengawali tradisi tulis dan menghasilkan karyakaryanya. Kegiatan tradisi tulis tersebut kemudian dilanjutkan oleh anak dan keturunannya (Hassan, 2007: 2). Tradisi tulis yang diawali oleh Raja Ahmad dan berlanjut pada generasi berikutnya, yakni cucu-cucunya sangat produktif dalam mengarang dan menulis berbagai aspek ilmu pengetahuan. Keluarga besar ini telah mengarang berbagai bentuk tulisan dalam kesusasteraan Melayu seperti syair, gurindam, hikayat dan lain sebagainya.

Selanjutnya, menurut Matheson, sepanjang abad ke-19, telah tercatat sebanyak 24 orang penulis Riau Lingga. Mereka menulis dari berbagai aspek seperti hukum, sastra, sejarah, dan agama. Betapa maraknya tradisi tulis sebagai suatu aktivitas intelektual pada saat itu sehingga tidak terlalu berlebihan jika abad ke-19 dikatakan sebagai zaman kegemilangan Riau dalam tradisi tulis. Keadaan ini dipengaruhi oleh kedatangan ulama dan sarjana-sarjana muslim dari seluruh Nusantara bahkan juga dari Timur Tengah. Hal ini terlihat ketika pemerintahan Yang Dipertuan Muda VII Sultan Abdul Rahman (1833-1844) beberapa ulama datang ke Riau, seperti Syekh Habib al-Shaggaf, Sayid Hassan alHaddad, dan Syekh Ahmad Jibrati dari Timur Tengah. Kemudian, Abdul Rahman membangun sebuah mesjid yang digunakan tidak hanya untuk ibadah ritual tetapi juga untuk berdiskusi tentang masalah-masalah ilmu pengetahuan dan agama, yakni Mesjid Besar Pulau Penyengat. Mesjid ini menjadi simbol perkembangan ilmu pengetahuan dan budaya Melayu (Hassan, 2007: 2; Matheson 1987).

Semasahidupnya, Raja Haji Daud sempatmengarang dan menulis tiga buah karya, yakni: (1) Risalah Asal Ilmu Tabib (RAIT); (2) Syair Peperangan Pangeran Syarif Hasyim; dan (3) Syair Siarah Said Qasim. Risalah Asal IImu Tabib (RAIT) menjelaskan tentang keseimbangan unsur dalam tubuh manusia guna menghindari penyakit. Hal ini dapat dipahami karena Raja Haji Daud pada masa hidupnya berprofesi sebagai tabib di Kerajaan Riau Lingga. Sampai sekarang dapat disaksikan bekas gedung tabib kerajaan tersebut di Pulau Penyengat. Sisa gedung Engku Haji Daud ini hanya berupa empat bidang dinding tembok dengan beberapa buah kerangka pintu dan jendela. Bekas gedung ini banyak menarik pengunjung karena, di samping merupakan peninggalan sejarah, juga terletak di tengah pemukinan yang ramai. Raja Haji Daud merupakan tabib kerajaan yang 
karya-karyanya ditulis dengan dilandasi atau dilatarbelakangi oleh agama Islam. Abu Hasan Sham mengatakan bahwa sebagai seorang tabib, Raja Haji Daud dikenal dengan nama Raja Daud Tabib (Sham, 1995: 60; Hamidi 1982).

\section{Kandungan Teks Risalah Asal IImu Tabib}

RAIT mengandung empat pasal, yaitu: (1) Pasal Pertama tentang warna tubuh dan perangai; (2) Pasal Kedua tentang kelakuan penyakit; (3) Pasal Ketiga tentang air kencing; dan (4) Pasal Keempat tentang menjamah nadi. Sebelum penjelasan pasal demi pasal, terlebih dahulu dijelaskan mengenai penciptaan alam dan manusia.

Telah diketahui umum bahwa alam dan bumi dihuni oleh berbagai makhluk. Alam dan manusia merupakan satu kesatuan di mana segala unsurnya berada dalam keadaan seimbang dan saling berfungsi untuk menciptakan keadaan yang baik antara manusia dan alam. Masingmasing mengikuti alur perjalanan sendiri sehingga lahir ketenteraman di dunia. Menurut Zainal Kling (1997: 56) konsep alam itu terdiri dari tiga yaitu: (1) alam tabi'i, dunia tempat manusia berpijak; (2) alam manusia dengan segala peraturan dan susunannya; (3) alam gaib dengan segala isi dan penghuninya. Manusia diciptakan setelah alam diciptakan. Berikut dijelaskan tentang unsur penciptaan manusia yang terkandung di dalam RAIT.

\section{Unsur Penciptaan manusia}

Sebelum menjelaskan keempat pasal yang tertulis di dalam naskah RAIT, terlebih dahulu pada halaman pertama dituliskan mengenai penciptaan alam dan manusia yang terdiri dari empat unsur yakni angin, api, air dan tanah. Angin lambang dingin, sedangkan api lambang panas, dan air melambangkan basah, sementara tanah melambangkan kering. Hal ini tertulis pada halaman pertama sebagai berikut:

Sebermula telah berkata hukama bahwa Allah Subhānahu wata'ala menjadikan dia akan dunia ini dan barang yang di dalamnya itu daripada empat perkara dinamai akan dia empat anasir yaitu pertama angin kedua api ketiga air dan keempat tanah maka angin itu sejuk dan api itu panas air itu 
basah dan tanah itu kering maka disusun jasad anak Adam daripada empat itu bercampur.11

Apabila dicermati mengenai unsur penciptaan manusia, maka angin, api, air dan tanah tersebut merupakan empat unsur yang bersatu di dalamnya. Hal ini bersesuaian dengan apa yang terkandung di dalam Al-Qur'an yang menjelaskan unsur tubuh manusia yang tergambar dalam proses penciptaannya, antara lain terdapat dalam Sūrah al-Mu'minūn (23) ayat 12-14 sebagai berikut.

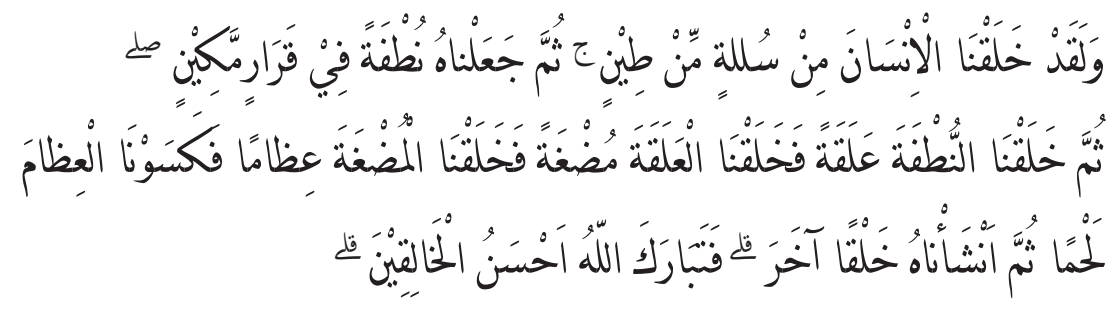

Artinya: Dan sesungguhnya Kami telah menciptakan manusia dari suatu saripati (berasal) dari tanah. Kemudian kami jadikan saripati itu air mani (yang disimpan) dalam tempat yang kokoh (rahim). Kemudian air mani itu Kami jadikan segumpal darah, lalu segumpal darah itu Kamijadikan segumpal daging dan segumpal daging itu Kami jadikan tulang belulang, lalu tulang belulang itu Kami bungkus dengan daging. Kemudian Kami jadikan dia makhluk yang (berbentuk) lain. Maka Mahasuci Allah, Pencipta Yang Paling Baik.

Berdasarkan ayat di atas, secara badaniah manusia diciptakan dari tanah dengan melalui proses evolusi, mulai dari tanah hingga menjadi manusia. Tanah adalah sumber atau evolusi pertama dan manusia merupakan evolusiyang terakhir (Qutub, 1971: 60). Lebih lanjut dijelaskan pula bahwa keempat unsur yang digunakan untuk menciptakan tubuh manusia sebagaimana yang terkandung dalam RAIT juga bersesuaian dengan pendapat Qutub yang menjelaskan tentang unsur penciptaan manusia yang terdiri dari angin, api, air dan tanah tersebut terurai pada tujuh tahap kejadian manusia, yakni:

1. Saripati tanah (sulālah min tīn), seperti penciptaan Adam

11 RAIT, h. 1. 
yang berasal dari tanah atau al-tīn. Ada beberapa istilah yang digunakan dalam Al-Qur'an mengenai asal mula kejadian manusia, yaitu turāb, tin, salsāl, dan hamā'in masnūn.

2. Nutfah atau air mani lelaki yang berasal daripada tanah dan telah bercampur dengan ovum wanita melalui proses hubungan seksual atau suntikan dan tersimpan dalam rahim wanita. Air ini muncul dari sulbi lelaki dan dada perempuan. Dalam Surah alTariq ayat 5-7 dijelaskan:

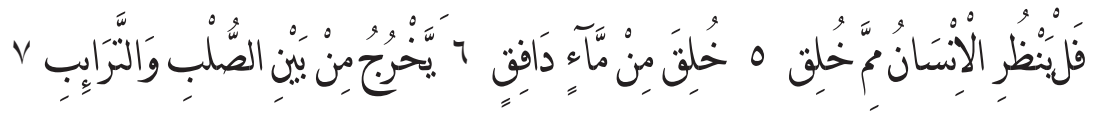

Artinya: Maka hendaklah manusia memperhatikan dari apakah dia diciptakan? Dia diciptakan dari air mani yang terpancar di antara tulang sulbi dan tulang dada.

3. 'Alaqah, yakni nutfah yang merupakan setetes air mani yang tergenang berubah menjadi 'alaqah (darah beku). Dalam AlQur'an pada Surah al-'Alaq ayat 2, yang terjemahannya: “Dia (Allah) telah menciptakan manusia dari 'alaq'. Kata 'alaq adalah jamak dari kata 'alaqah. Menurut istilah, 'alaqah diartikan sebagai darah beku, karena evolusi kejadian manusia pada tahap ini berbentuk darah beku yang menempel di dinding rahim wanita (Manzur, 1990: 261). Al-Qurtubi (1967: 119) menyebutkan, 'alaqah adalah sepotong darah yang basah; apabila darah tersebut kering, maka ia tidak akan tergantung atau menempel ('alaqah).

4. Mudghah (daging) yang berasal dari darah beku yang menempel di dinding rahim ('alaqah) berubah menjadi daging.

5. ' ' żām (tulang) dari daging yang sepotong itu berubah menjadi tulang ('iẓām).

6. Tulang yang berasal dari daging itu ditutupi dengan daging sehingga membentuk rangka manusia.

7. Akhirnya Tuhan menjadikan dalam rangka tersebut janin dengan ditiupkan roh kepadanya sehingga ia pun siap untuk dilahirkan (Qutub, 1971: 60). 
Selain Al-Qur'an, proses penciptaan manusia juga dijelaskan dalam sabda Rasul yang artinya adalah sebagai berikut:

Diterima dari Abdullah, dia berkata: Rasul telah menceritakan kepada kami bahwa kejadian salah seorang kamu berkumpul dalam perut ibunya selama 40 hari, setelah itu ia berubah menjadi segumpal darah selama itu juga, dan kemudian segumpal darah itu menjadi segumpal daging selama yang demikian itu juga. Selanjutnya diutus kepadanya seorang malaikat, maka ditiupkan roh kepadanya dan dia diperintahkan menentukan empat hal yaitu rezeki, ajal, amal dan nasibnya yang baik atau buruk. ${ }^{12}$

Apabila diperhatikan lebih seksama, hadis ini tidak hanya menggambarkan proses kejadian manusia tahap demi tahap saja tetapi juga menjelaskan waktu yang ditempuh pada tahap-tahap tersebut terutama pada masa nutfah,'alaqah dan mudgah yang masingmasingnya selama 40 hari. Dalam kajian biologi menurut Becketh ketika nutfah sudah berusia lima minggu ia berkembang atau berubah menjadi embrio yang ukuran panjangnya sekitar $5 \mathrm{~mm}$. Pada masa ini otak, mata, telinga, serta hati sudah mulai tumbuh.

Kemudian terdapat pula gumpalan kecil yang terletak di samping yang akan menjadi tangan dan ekor. Pada usia enam minggu panjangnya bertambah menjadi $13 \mathrm{~mm}$. Ketika ini muka dan lengan sudah terlihat seperti manusia. Setelah berumur delapan minggu ia sudah terlihat benar-benar seperti manusia dengan organ tubuh yang sudah lengkap. Menjelang usia ke delapan bulan, janin sudah memiliki panjang $35 \mathrm{~cm}$ dan telah memiliki rambut. Pada usia sembilan bulan, ia sudah menjadi seorang bayi seberat antara $3 \mathrm{~kg}$ s/d $3.5 \mathrm{~kg}$ dan panjang sekitar $50 \mathrm{~cm}$ (Becketh, 1978: 59). Artinya, proses kejadian manusia dalam kandungan dimulai dari semenjak sperma bergabung dengan ovum wanita. Kemudian berubah membentuk beberapa sel dan setelah beberapa lama, ia kemudian menempel di dinding rahim (Roza, 2013: 172).

Selanjutnya dikatakan oleh Noor Azlan Mohd. Nor (1993) bahwa keempat unsur yang terkandung dalam proses penciptaan manusia tersebut memainkan peranan penting dalam tubuh manusia. Sebagai

12 Sahih Muslim t.th, Jilid II, h. 401- 402. 
contoh, seandainya hendak memilih jodoh, perkiraan tarikh lahir mengikut unsur seperti tanah, api, angin, dan air yang akan menjadi kayu pengukurnya. Seandainya perkiraan mendapati lelaki itu api maka sudah tentu calon perempuan tersebut di bawah unsur air. Penyesuaian perkiraan ini dilakukan supaya kehidupan keluarga mereka nanti serasi, aman, dan damai hingga ke anak cucunya kelak (Nor, 1993: 56-57).

\section{Penyakit Tubuh Manusia}

Sakit pada umumnya terbagi menjadi dua golongan, yaitu: (1) sakit yang tampak; dan (2) sakit yang tidak tampak. Sakit yang tampak adalah sakit yang terjadi pada tubuh manusia. Sedangkan sakit yang tidaktampak adalah penyakit yang terjadi pada perasaan dan mental seseorang. Dalam hal ini, penyakit yang diderita seseorang tidak terlihat wujudnya karena yang sakit bukan tubuhnya tetapi jiwa atau batinnya. Kedua jenis penyakit tersebut selalu ada pada manusia meskipun datangnya tidak bersamaan (Roza, 2013: 200). Sakit dan sehat bagi seorang mukmin sama baiknya sebab keduanya datang dari Allah swt. dan segala sesuatu yang datang dari-Nya pasti mengandung hikmah (Roza, 2013: 185). Dalam keadaan sakit, seorang mukmin tidak selayaknya melihat negatifnya sebagai musibah semata. Misalnya, di antara hikmah suatu penyakit bagi seseorang adalah dapat menjadi penghapus (kaffarat) (Al-Utsaimin, 2003: 11). Selain itu, penyakit juga dapat mengingatkan seseorang akan pentingnya nilai kesehatan sehingga selalu menjaganya. Menurut pakar medis, di dalam tubuh manusia terdapat bakteri yang tidak akan mati kecuali dengan penyakit tertentu (Tambusai, 2010: 13).

Berdasarkan pengamatan di masyarakat, sebagian besar penyakit dipercayai berasal dari makanan yang tidak seimbang. Sebagaimana yang telah dijelaskan bahwa tubuh manusia terdiri dari empat unsur yang seimbang yakni angin, api, air dan tanah. Keempat unsur tersebut apabila seimbang keberadaannya di dalam tubuh, maka menjadikan tubuh manusia sehat dan tahan terhadap penyakit. Sebaliknya, apabila tidak seimbang keempat unsur tersebut, maka penyakit pun segera datang. Sebagaimana yang tertulis pada halaman 1-2 bahwa :

Syahdan, maka apabila terlebih satu suatu daripada yang empat itu atas jasad manusia atau kurang, maka itulah menjadi penyakit dan apabila bersamaan 
keempatnya itu menjadi sehat adanya. Maka apabila terlebih atau kurang salah suatu daripada yang empat itu maka hendaklah bicarakan obatnya yang berlawanan misalnya lebih itu panas maka beri pula lawannya yang sejuk dan jika yang lebih itu sejuk maka beri pula lawannya yang panas supaya bersamaan keempatnya itu. ${ }^{13}$

Menurut Colson (1970) penjagaan kesehatan mempunyai dua aspek: Pertama, yang bercorak positif yang bertujuan memastikan kesehatan secara kontinu; dan kedua, bercorak negatif yang bertujuan menghalang penyakit atau mengobati penyakit. Selanjutnya dalam hal pencegahan penyakit yang berkaitan dengan makanan ada beberapa tips dari Rasulullah saw di antaranya adalah:

1. Jangan makan kecuali ketika lapar dan jangan makan sampai lambung kekenyangan;

2. Jangan menghimpunkan atau mengumpulkan makanan yang sifatnya sama sekaligus seperti memakan daging dan telur karena makanan tersebut bersifat panas;

3. Jangan menghimpunkan makanan yang bersifat dingin karena akan mengganggu keseimbangan enzim pencernaan;

4. Jangan menghimpun atau mengumpulkan makanan yang samasama basah atau makanan yang sama-sama keringnya, namun kombinasikan keduanya;

5. Sselalu mencampurkan dua jenis makanan agar yang satu bisa menetralkan kekurangan yang lainnya;

6. Jangan memakan makanan berlendir yang kurang masaknya;

7. Jangan langsung minum sehabis makan karena akan mengganggu kinerja enzim dan keasaman lambung dalam mencerna makanan; dan

8. Minumlah setengah jam sebelum dan sesudah makan (Assegaf, 2011: 35-38).

\section{Tanda-tanda penyakit}

Untuk mengetahui penyakit yang menyerang tubuh, seseorang dapat melihat gejala-gejala dan tanda-tanda yang ada pada orang yang

13 RAIT, h. 1-2. 
sakit. Gejala tersebut dapat berupa rasa panas atau dingin. Kemudian dapat pula diketahui dari suhu badannya, apakah normal atau tidak. Selain itu, dapat juga diketahui dari warna buang air besar atau air kecil. Juga dapat dirasakan melalui tekanan denyut nadinya, lemah atau kuat. Sedangkan yang paling umum adalah dengan mengukur tekanan darah, tinggi atau rendah. Tanda-tanda umum seperti yang disebutkan di atas sesuai dengan apa yang terkandung di dalam RAIT yang tertulis pada halaman ke-2 sebagai berikut:

Adapun jalan mengetahui tabiat penyakit itu beberapa perkara dan setengah daripadanya dilihat kepada warna tubuhnya dan perangainya. Setengahnya itu dilihat kepada kelakuan penyakitnya itu dan setengah daripadanya dilihat kepada warna kencingnya dan tahinya dan setengah daripadanya dilihat kepada denyut nadinya yaitu terlebih sukar bicaranya lagi.

\section{Jenis-jenis Penyakit}

Selanjutnya, berdasarkan empat unsur yang terkandung dalam tubuh manusia yakni angin, api, air dan tanah, penyakit yang tumbuh subur pada tubuh seseorang juga empat jenis sifatnya. Demikian yang terkandung di dalam naskah RAIT halaman 1-2:

Disusun jasad anak Adam daripada empat itu bercampur dan dinamai akan dia empat tabiat. Pertama, ash-shafrawi yakni sakit mirrat dan tabiatnya itu panas kering yang jadi daripada asal api dan tempatnya itu di empedu. Kedua, as-sudawi yakni sakit pitam dan tabiatnya sejuk kering yang jadi daripada asal tanah tempatnya itu di limpa. Dan ketiga, al-balgami yakni sakit balgam lendir tabiatnya itu sejuk basah yang jadi daripada asal air tempatnya itu di paruparu. Dan keempat, ad-damawi yakni sakit darah tabiatnya itu panas basah yang jadi ia daripada asal angin dan tempatnya itu di hati. Maka daripada bercampur yang empat inilah yang menolong jasad anak Adam itu dan dengan dialah yang menenangkan jasad dan daripadanya yang membaikkan pada jasad dan yang membinasakan dia dengan kudrat Allah ta'ala.

\section{Ash-Shafrawi}

RAIT mencatatkan bahwa "ash-shafrawi yakni sakit mirrat dan tabiatnya itu panas kering yang jadi daripada asal api dan tempatnya 
itu di empedu". ${ }^{14}$ Kata ash-shafrawi berasal dari kata Arab yang berarti penyakit kuning (Yunus, 1973: 218). Sedangkan mirrat artinya empedu (Yunus, 1984: 815). Penyakit kuning merupakan penyakit yang menyerang empedu. Apabila penyakit ini diderita oleh seseorang, maka ia akan merasakan panas dan mulutnya berasa kering sehingga merasakan haus. Hal demikian dikarenakan penyakit kuning berasal dari unsur api. Oleh karena itu, orang yang menderita atau dikenai penyakit shafrawi, muka dan kulit badannya berwarna kuning. Pada masyarakat dikenal dengan sebutan "penyakit kuning." Orang yang terkena penyakit kuning, tubuhnya biasa-biasa saja, dalam arti tidak gemuk dan tidak pula kurus tetapi tubuhnya berwarna kuning. Di dalam RAIT juga disebutkan bahwa "bagi yang mempunyai tabiat shafrawi yaitu tiada kurus dan tiada gemuk, sederhana tubuhnya dan warnanya kuning.

Empedu adalah organ badan manusia yang berukuran sebesar empat inci dan berperan untuk membantu sistem pencernaan manusia dalam memecah lemak dari makanan serta melepas isi cairan pada usus kecil. Empedu digunakan oleh usus kecil untuk menguraikan lemak dari makanan yang masuk ke tubuh sehingga tubuh akan mendapatkan vitamin dan mineral yang dibutuhkan.

Gejala gangguan empedu yang paling umum adalah: (1) Nyeri yang dirasakan di bagian tengah sampai kanan atas perut. Nyeri cenderung akan bertambah parah jika memakan makanan berlemak. Dalam kasus yang lebih serius, nyeri dapat menyebar ke punggung atau ke atas, bahkan dapat terasa di dada; (2) Demam, pertanda bahwa tubuh sedang melawan infeksi. Demam yang disertai nyeri perut di daerah empedu seharusnya tidak boleh didiamkan saja. Infeksi harus ditangani secepat mungkin karena dapat menyebar ke bagian tubuh lainnya; (3) Mengigil, mengigil biasanya terjadi bersamaan dengan demam yang disebabkan oleh infeksi; (4) Kulit berwarna kuning, kondisi ini dapat menunjukkan adanya batu atau penyumbatan di saluran empedu; (5) Berkeringat secara berlebihan; (6) Tinja yang berwarna cerah; (7) Urin yang berwarna gelap; (8) Kehilangan nafsu makan; dan (9) Detak jantung yang sangat cepat (Juned, 2011: 77).

Empedu akan mengalami gangguan jika tidak terjadi keseimbangan

${ }^{14}$ RAIT, h.1. 
unsur yang terkandung di dalam tubuh manusia. Empedu berasal dari unsur api yang memiliki sifat panas. Oleh karena itu, ketika makan harus diperhatikan keseimbangan makanan yang dimakan; artinya jangan mengkosumsi makanan yang mengandung panas terlalu banyak akan tetapi harus mengkombinasikannya dengan yang dingin. Rasulullah saw. selalu mencampurkan dua jenis makanan agar yang satu bisa menetralkan kekurangan yang satunya sehingga terjadi keseimbangan. Dengan demikian, tubuh akan tetap terkontrol dan stabil kondisinya sehingga tidak berpotensi menimbulkan penyakit (Al-Hulwani, 2006: 37).

Dengan tidak adanya keseimbangan makanan yang dikosumsi manusia, maka terjadi penumpukaan kolesterol atau timbunan kalsium yang lama-kelamaan akan mengeras dan menjadi batu empedu. Batu empedu tersebut dapat timbul di dalam kantung empedu atau di saluran empedu yang merupakan saluran penghubung antara kantung empedu dan usus kecil. Batu empedu memiliki ukuran yang beragam, mulai dari 1-2 sampai 3-5 millimeter dan terkadang jumlahnya lebih dari satu. Batu empedu juga cenderung bertambah besar apabila tidak diobati sehingga dapat meningkatkan resiko penyumbatan.

\section{As-Sudawi}

As-sudawi dalam bahasa Arab mengandung arti lemah, tidak semangat. ${ }^{15}$ Sebagaimana yang tertulis di dalam naskah RAIT bahwa "as-sudawi yakni sakit pitam dan tabiatnya sejuk kering yang jadi daripada asal tanah tempatnya itu di limpa". ${ }^{16}$ Sakit pitam adalah sakit yang menyerang syaraf bagian kepala di mana kepala akan terasa berat dan pandangan mata berkunang-kunang. Dalam kondisi tersebut tubuh manusia akan terasa lemah dan keringat banyak keluar karena yang diserang adalah limpa. Limpa adalah organ yang berukuran sebesar kepalan kecil yang terletak pada sisi kiri perut dan pankreas yang memproduksi insulin, yakni hormon untuk mengatur gula darah. Apabila gula darah meningkat, maka badan akan terasa lemah. Dalam kehidupan sekarang dikenal dengan sebutan penyakit diabetes.

Limpa adalah bagian dari sistem kekebalan tubuh. Limpa mengatur

\footnotetext{
${ }^{15}$ Al-Munawir, Kamus Almunawir Arab-Indonesia, h.1099.

${ }^{16}$ RAIT, h. 1.
} 
produksi trombosit, yaitu jenis sel darah yang penting untuk pembekuan darah. Kemudian limpa juga dapat menyimpan trombosit dan juga membantu dalam pengaturan cairan di dalam tubuh. Demikian juga limpa memiliki kemampuan untuk menyaring sel darah merah. Apabila limpa manusia terganggu kesehatannya, maka akan terlihat berbagai tanda pada tubuh manusia seperti kelelahan, lemah otot, pembengkakan pada tangan dan kaki, infeksi kronis, mudah terjadi pendarahan, yang pada akhirnya menyebabkan anemia dan leukopenia (Hen, 2014: 60).

Berdasarkan keterangan di atas, dapat dikatakan bahwa limpa akan mengalami gangguan jika tidak terjadi keseimbangan unsur yang terkandung di dalam tubuh manusia. Limpa berasal dari unsur tanah yang memiliki sifat sejuk dan kering. Oleh karena itu, ketika makan harus diperhatikan keseimbangannya; jangan mengkosumsi makanan yang mengandung dingin akan tetapi harus mengkombinasikannya dengan yang lain, sebagaimana hal ini juga dilakukan oleh Rasulullah saw (Gray, 2012: 23). Dengan demikian, tubuh akan tetap terkontrol dan stabil kondisinya sehingga tidak berpotensi menimbulkan penyakit. Limpa memainkan peran penting dalam sistem kekebalan tubuh. Tidak adanya limpa dalam tubuh tidak dianggap fatal, tapi itu membuat manusia lebih rentan terhadap infeksi.

\section{Al-Balgami}

Dalam RAIT tertulis bahwa "al-balgami yakni sakit balghom lendir tabiatnya itu sejuk basah yang jadi daripada asal air tempatnya itu di paru-paru". Kata al-balgami berasal dari kata Arab yang mengandung arti lendir, dahak (Yunus, 1984: 72). Jenis penyakit ini sangat berkaitan dengan cairan berupa lendir dan dahak yang terdapat di saluran antara hidung dan mulut hingga ke saluran pernafasan di paru-paru. Biasanya sering dirasakan manusia ketika baru bangun dari tidur seolah-olah ada rasa yang tersekat-sekat dekat hidung.

Paru-paru adalah organ yang berperan dalam sistem pernafasan, dimana terdapat pertukaran oksigen dan juga pertukaran karbondioksida di dalam darah. Apabila fungsi paru-paru mengalami gangguan karena satu dan lain hal, maka berpengaruh pula bagi kesehatan manusia dan harus ditangani dengan seksama. Penyakit paru-paru cenderung menghasilkan lendir di daerah tenggorokan. Untuk menghindarinya 
tentu saja harus mengurangi makanan yang dapat merangsang timbulnya lendir seperti makanan yang mengandung terlalu manis dan bahan yang dingin (Al-Hulwani, 2006: 11). Adapun tanda-tanda seseorang kena penyakit balgami disebutkan dalam RAIT sebagai berikut:

Sebermula yang nyata daripada penyakit balgami itu diperolehnya lemah segala sendi-sendi dan berat segala anggota dan demam berturut-turut dan sukar beranak kepada perempuan dan putih pada mata dan belang dan mati sebelah anggota dan kudis dan batuk yang basah dan lupakan dir.i. ${ }^{17}$

Untuk menghindari penyakit jenis ini, manusia harus menyeimbangkan makanan yang diasup ke dalam tubuh. Dikarenakan jenis penyakit al-balgami adalah sejuk dan basah, maka diimbangi dengan makanan yang bersifat panas seperti yang dilakukan oleh Rasulullah saw., yaitu selalu mencampurkan dua jenis makanan agar yang satu bisa menetralkan kekurangan yang lainnya (Assegaf, 2011: 17).

Sebenarnya lendir hidung atau ingus adalah cairan kental dan lengket yang berfungsi sebagai filter terhadap partikel udara yang tidak diinginkan untuk mencegahnya masuk ke dalam tubuh melalui hidung. Cairan lendir ini merupakan bagian alami dari pertahanan tubuh, namun terkadang dihasilkan secara berlebihan. Lendir yang dihasilkan terlalu banyak bisa membuat seseorang terganggu. Cara yang terbaik untuk menghilangkan lendir dari saluran hidung adalah dengan menentukan penyebabnya dan mengatasi masalah tersebut.

Paling tidak ada tiga jenis penyakit paru-paru yang paling banyak diderita manusia, yaitu: (1) Asma, yakni penyakit yang menyerang saluran pernafasan. Biasanya ditandai dengan sesak nafas yang bisa datang dan pergi sewaktu-waktu karena saluran nafasnya yang sensitif bereaksi sehingga menyempit. Selain itu ciri-ciri penyakit paru-paru asma lainnya adalah muncul bunyi mencuit saat bernafas, batuk, nafas pendek hingga dada terasa sesak; (2) Tuberkulosis (TBC), yakni penyakit paru-paru yang ditandai oleh adanya batuk berdahak lebih dari 3 minggu dan juga dapat disertai batuk berdarah. Selain itu, penderita mengalami demam pada sore dan pagi hari dan pada saat malam akan berkeringat. Nafsu makan

\footnotetext{
${ }^{17}$ RAIT, h. 3.
} 
pun akan menurun; dan (3) Kanker paru-paru merupakan penyakit yang disebabkan oleh asap rokok yang banyak mengadung zat beracun. Bukan hanya perokok aktif saja yang dapat terkena kanker paru-paru tetapi juga perokok pasif mempunyai resiko terserang kanker paru-paru, bahkan persentasenya lebih besar dibanding dengan perokok aktif, karena perokok pasif menghirup langsung asap yang dikeluarkan perokok aktif.

\section{Ad-Damawi}

Ad-damawi yakni sakit darah tabiatnya itu panas basah dan asalnya angin sedangkan tempatnya di hati. Kata ad-damawi juga berasal dari bahasa Arab, "dāmun" yang berarti darah (Yunus, 1984: 130). Dengan demikian ad-damawi adalah jenis penyakit yang berkaitan dengan darah. Dalam RAIT tertulis bahwa "ad-damawi yakni sakit darah tabiatnya itu panas basah yang jadi ia daripada asal angin dan tempatnya itu di hati".

Hati adalah organ yang bekerja paling keras di dalam tubuh. Berukuran seperti bola kecil yang berada tepat di bawah tulang rusuk di sisi kanan perut. Hati sangat penting untuk mencerna makanan, menyingkirkan zat beracun dari tubuh, dan menyimpan energi bagi tubuh untuk digunakan bila diperlukan. Penyakit hati dikenal dengan istilah penyakit liver, yaitu penyakit yang disebabkan oleh berbagai faktor yang merusak hati, di anataranya adalah karena tidak adanya keseimbangan makanan di dalam tubuh, seperti penggunaan alkohol yang banyak.

Ciri-ciri orang yang kena penyakit di hati dalam RAIT dituliskan sebagai berikut:

Sebermula yang nyata daripada penyakit damawi itu diperolehnya lemah (dha'if) badan dan sangat dahaga dan sedikit tidur dan kering muka dan kepala dan penyakit gugur rambut dan terkupas kulit dan pucat muka. 18

Jenis yang paling umum dari infeksi hati adalah virus hepatitis termasuk hepatitis A, hepatitis B, dan hepatitis C (Mardiah, et.al., 2006: 77). Hepatitis tidak hanya disebabkan oleh adanya virus dari berbagai jenis hepatitis, namun ada pula yang disebabkan oleh adanya toksin atau racun, serta efek samping dari obat-obatan kimia, makanan yang

18 RAIT, h. 3. 
banyak mengandung bahan pengawet, dan bahan kimia lainnya juga melatarbelakangi organ hati mengalami peradangan. Artinya, terjadinya penyakit yang menyerang hati dikarenakan tidak adanya keseimbangan makanan yang dimakan manusia. Selain itu, terjadi pula perubahan warna kulit menjadi kuning. Hal tersebut juga tertulis dalam RAIT: "dan yang mempunyai tabiat damawi itu tubuhnya tambung gemuknya dan kuning kulitnya dan matanya merah." Hal ini disebabkan oleh cairan empedu yang meningkatkan kadarnya dalam darah.

Penyakit hati sebelum menjadi kronis, sel-sel hati yang rusak tumbuh menjadi tumor hati yang jinak (benigna) dan ganas (maligna). Kemudian, hati akan mengalami perlemakan yang selanjutnya hati akan membengkak (fatty liver). Tumor jinak atau ganas menyebabkan hati mengalami pembesaran dan perdarahan ke dalam rongga perut (Mardiah, et.al., 2006: 77).

\section{Penutup}

Berdasarkan analisis terhadap kandungan naskah RAIT, manusia diciptakan oleh Sang Pencipta, Allah, Tuhan Yang Maha Esa, terdiri atas empat unsur, yakni angin, api, air, dan tanah. Berdasarkan asal penciptan tersebut, keseimbangan empat unsur harus terus tetap dijaga oleh manusia agar tidak ada satu unsur yang lebih dominan daripada unsurunsur lainnya, yang dapat menyebabkan timbulnya penyakit. Karena, jika terjadi ketidakseimbang antara empat unsur tersebut, maka tubuh manusia akan sakit. Selanjutnya, penyakit yang bersarang di dalam tubuh manusia pada umumnya ada di empat tempat, yaitu: empedu, limpa, paru-paru, dan hati. Apabila kelebihan atau kekurangan unsur api, maka akan menimbulkan penyakit yang menggrogoti empedu dan sekitarnya; apabila kelebihan atau kekurangan unsur tanah, maka akan menggrogoti limpa dan sekitarnya; apabila kelebihan atau kekurangan unsur air, maka akan menimbulkan penyakit yang menyerang paru-paru dan sekitarnya; dan apabila kelebihan atau kekurangan unsur angin, maka akan menimbulkan penyakit yang menggrogoti hati dan sekitarnya.

Selanjutnya, manusia baru merasa pentingnya sehat adalah ketika penyakit telah menghampiri dirinya. Barangkali itulah sebabnya Rasulullah saw. mengingatkan manusia agar senantiasa menjaga kesehatan sebelum datangnya suatu penyakit. Oleh karena itu, menjaga 
kesehatan lebih dianjurkan daripada mengobati penyakit. Ketika sehat, manusia hendaknya menjaga keseimbangan empat unsur, api, air, tanah, dan angin tersebut agar anugerah kesehatannya tetap terjaga dan terpelihara.

\section{Bibliografi}

Abdullah, M. Amin. 2002. Studi Agama Normativitas atau Historisitas? Yogyakarta: Pustaka Pelajar.

Abdullah, M. Amin 2007. Islamic Stadies dalam Paradigma IntegrasiInterkoneksi. Yogyakarta: SUKA Press.

Al-Attas, Syed Muhammad Naquib. 1984. Konsep Pendidikan dalam Islam.terj. Haidar Bagir. Bandung: Mizan,

Al- Anshari, Ibnu Manzur Jamaluddin. 1990. Lisān al-'Arab. Beirut: Dar al- Sadir.

Al-Hulwani, Thal'at bin Fu'ad, 2006. Pengobatan Cara Nabi. Jakarta: Darul Haq

Al-Utsaimin. 2003. Syarh Al-Aqidah Al-Wasithiyah li Syaikh Al-Islam Ibni Taimiyah. Beirut: Dar Al-Hikam Ad-Diniyyah.

Al-Qurtubi, Abī Abd Allah Muhammad ibn Ahmad al- Ansāri. 1967. Al- Jami' al-Bayān li ahkām al- Qur'ān.Kairo: Dār al-Kutub al-' Arabiyah.

Ambary, Hasan Muarif. 2005. "Kontribusi Filologi, Sejarah dan Arkeologi bagi Pengembangan Kebudayaan Indonesia". Jurnal Lektur Keagamaan. 3(1): 90-103. Jakarta: Puslitbang Lektur Keagamaan Depag RI.

Becketh. 1978. Illustrated Biology. London: Oxford University Press.

Colson, A.C. 1970. The Preventition of Illness in a Malay Village:

an Analysis of Councept and Behavior. Ph.D. Thesis. Stanford University.

Daruzzah. t.th, Al-Tafsìr al- Hadīth. t.tp.: Dār Ihyā al-Kutub al- 'Arabiyah. Djamaris, Edwar. 2000. Metode Penelitian Filologi. Jakarta: Bumi Aksara.

Ekadjati, Edi S. 2000. Direktori Edisi Naskah Nusantara. Jakarta: Yayasan Obor Indonesia.

Endaswara, Suwardi. 2006. Metode, Teori, Teknik Penelitian Kebudayaan. Yogyakarta: Pustaka Widyataman. 
Fathurrahman, Oman. dkk. 2010. Filologi dan Islam Indonesia. Jakarta:

Balitbang dan Diklat Keagamaan Depag RI.

Faturrahman, Oman. 2010. "Filologi Plus: Metode dan Pendekatan.

Makalah pada Temu Peneliti Naskah Keagaman Puslitbang Lektur

Keagamaan. Bukittinggi.

Gray, Jerry D. 2012. Rasulullah is My Doctor. Johor: Pustaka Noor. Hamidi,UU. Naskah Kuno Daerah Riau. Pekanbaru. 1982/1983.

Hartono. 2011. Metodologi Penelitian. Pekanbaru: Zanafa Publising. Hamid, Rogayah A. dan Mariam Salim. 2006. Kepustakaan IImu

Tradisional. Kuala Lumpur: Dewan Bahasa dan Pustaka.

Helmiati dan Alimuddin Hassan. 2007. Genealogi Intelektual dan

Pemikiran Islam Abad ke-19 di Kerajaan Melayu Riau. Pekanbaru:

Hasil Penelitian LPPM UIN Suska Riau.

Juned, Pehin Awang Abdul Aziz. 2011. Berubat dengan Perubatan

Bumi dan Langit. Selangor: Al-Hidayah House of Publishers SDN. BHD.

Karim, Ab. Razak Ab. 2002. "Kitāb Țibb : Kepelbagaian Jenis Penyakit dan Bahan-bahan Perubatan“. Jurnal Filologi Melayu. Vol. 10.

Kuala Lumpur: Perpustakaan Negara Malaysia.

Kling, Zainal. 1997. "Adat: Dasar Budaya Melayu". dalam Kebudayaan

Nusantara Kepelbagaian dalam Kesatuan. Kuala Lumpur: Dewan Bahasa dan Pustaka Malaysia.

Labib MZ. dan Maftuh Ahnan. Tt. Primbon Mujarrobat Kubra. Surabaya:

Bintang Usaha Jaya.

Lubis, Nabilah.2005. "Kajian Filologi di Indonesia". Jurnal Lektur Keagamaan. 3(1): 71-89. Jakarta: Puslitbang Lektur Keagamaan Depag RI.

Loir, Henri Chambert dan Oman Faturrahman. 1999. Khazanah Naskah

Panduan Koleksi Naskah-naskah Indonesia se-Dunia. Jakarta: Yayasan Obor Indonesia.

Marks, Harry J. 1959. The First Contest For Singapura 1819-1824. Gravenhage- Martinus Nijhoff.

Maloeng, Lexy J. 1997. Metode Penelitian Kualitatif. Bandung: Rosdakarya.

Mardiah, et.al. 2006. Makanan Antikanker. Jakarta Selatan: Agro Media Pustaka. 
Mariyah M.S. tt. Kumpulan Mujarrobat Lengkap. Surabaya: Mahkota. Matheson, Virginia. 1987. "Suasana Budaya Riau dalam abad ke-19: Latar Belakang dan Pengaruhnya". dalam Zarah Ibrahim. Tradisi Johor-Riau: Kertas Kerja Hari Sastra 1983. Kuala Lumpur: Dewan Bahasa dan Pustaka Malaysia.

Mohamad Zain, Shaharir. 2003. "Sains dan Teknologi Melayu sebelum Penjajahan Eropah", dalam Jurnal Melayu, 1(2): 157-204. Kuala Lumpur: Dewan Bahasa dan Pustaka.

Mu'jizah (Ed.). 2017. Dinamika Pernaskahan Nusantara. Jakarta: Manassa dan Yanassa.

Muhadjir. 2000. Metodoogi Penelitian Kualitatif. Yogyakarta: Rake Sarasian.

Mulyadi, SWR. 1994. "Kodikologi Melayu di Indonesia", Jurnal Lembar Sastra, No. 24. Depok: FASA UI.

Musa, Mohamad Zain dan Nik Hassan Shuhaimi Nik Abdul Rahman. 2010. "Peranan Budaya dalam Mempromosikan Keharmonisan di Asia Tenggara." Jurnal Terjemahan Alam dan Tamadun Melayu. 1(2): 183-189. Bangi: ATMA UKM.

Nasution, Syamruddin. 2014. "Kajian Naskah Kitab Sairu al-Salikin libabi Ihya'Ulumuddin Karya Syekh Ali ibn Abdurrahman al-Kalantani." Jurnal Sosial Budaya. 11(1): 70-90. Pekanbaru: UIN Suska Riau. Nazir, Mohd. 2000. Metode Penelitian. Jakarta: Bina Aksara. Netsher, Elisa. 1854. "Beschrijving van een gedeelte der residentie Riaouw". TBG. II.

Nor, Noor Azlam Mohd. 1993. "Sistem perubatan Malayu: Suatu

Tinjauan Umum". Perubatan Melayu dan Kesihatan di Kalangan Orang Melayu. Kuala Lumpur: Akademi Pengajian Melayu Universiti Malaya.

Osman, Mohd. Taib. 2006. "Kitab Ubat-ubat Melayu" dalam Rogayah

A. Hamid dan Mariam Salim. Kepustakaan IImu Tradisional. Kuala Lumpur: Dewan Bahasa dan Pustaka.

Piah, Harun Mat. 2006. Kitāb Tibb, IImu Perubatan Melayu. Kuala Lumpur: Kementerian Kebudayaan,Kesenian dan Warisan Malaysia.

Qutub, Saiyyid. 1971. Fì Zilāl al-Qur' ān. Beirut: Turās̀ al-'Arabi. Roza, Ellya. 2010. Asal Ilmu Tabib. Pekanbaru: Museum Sang Nila 
Utama Pekanbaru.

2011. Naskah Melayu. Pekanbaru: Yayasan Pusaka.

2013. "Negeri Dan Masyarakat Siak 1723-1908: Sebuah Kajian

Dari Aspek Sosio Budaya" Disertasi. tidak diterbitkan. Bangi: UKM . 2014. "Ramuan Herbal Non Instan dalam Naskah Kitab Tib sebagai Alternatif Pengobatan". Jurnal Sosial Budaya: Media Komuniokasi IImu-ilmu Sosial dan Budaya.11(1): 1-18.

Sham, Abu Hassan. 1995. Syair-syair Melayu Riau. Kuala Lumpur:

Perpustakaan Negara Malaysia.

Shafri, Mohd. Affendi Mohd. dan Intan Azura Shahdan. 2017. Malay Medical Manuscripts (Heritge From The Garden of Healing). Kuantan: The Islamic Manuscripts Assosiation.

Syaifullah. 2016. Pengaruh Ruqyah Syar'iyyah dalam Pengobatan Fisik di Propinsi Riau. Pekanbaru: LPPM UIN Suska Riau.

Sugiyono. 2013. Metode Penelitian Kuantitatif Kualitatif dan R\&D. Bandung: Alfabeta.

Soebadio, Haryati. 1975. "Filologi". Makalah Seminar Prasarana Daerah Bali-Sunda-Jawa. Yogyakarta.

Tambusai. 2010. Buku Pintar, Jin, Sihir \& Ruqyah Syar'iyyah. Jakarta:

Pustaka Al-Kausar.

Vredenbergt. J. 2002. Metode dan Teknik Penelitian. Jakarta: Gramedia. Webster, A. Merriem. 1967. Webster's Seventh New Collegiate Dictionary. Toronto: Thomas Allen \& Son Limited.

Yunus, Hasan. 2003. Engku Puteri Raja Hamidah Pemegang Regalia Kerajaan Riau. Pekanbaru: UNRI Press.

Ellya Roza, Universitas Islam Negeri Sultan Syarif Kasim II Riau. Email: ellya.roza@uin-suska.ac.id. 


\section{IIllonuskskripton \\ KETENTUAN PENGIRIMAN TULISAN}

\section{Jenis Tulisan}

Jenis tulisan yang dapat dikirimkan ke Manuskripta ialah:

a. Artikel hasil penelitian mengenai pernaskahan Nusantara

b. Artikel setara hasil penelitian mengenai pernaskahan Nusantara

c. Tinjauan buku (buku ilmiah, karya fiksi, atau karya populer) mengenai pernaskahanNusantara

d. Artikel merupakan karya asli, tidak terdapat penjiplakan (plagiarism), serta belum pernah ditebitkan atau tidak sedang dalam proses penerbitan

\section{Bentuk Naskah}

1. Artikel dan tinjauan buku ditulis dalam bahasa Indonesia atau bahasa Inggris dengan menggunakan kaidah-kaidah yang berlaku.

2. Naskah tulisan dikirimkan dalam format Microsoft Word dengan panjang tulisan 5000-7000 kata (untuk artikel) dan 1000-2000 kata (untuk tinjauan buku).

3. Menuliskan abstrak dalam bahasa Inggris dan bahasa Indonesia sebanyak 150 kata.

4. Menyertakan kata kunci (keywords) dalam bahasa Inggris dan bahasa Indonesia sebanyak 5-7 kata.

5. Untuk tinjauan buku, harap menuliskan informasi bibliografis mengenai buku yang ditinjau.

\section{Tata Cara Pengutipan}

1. Sistem pengutipan menggunakan gaya American Political Sciences Association (APSA).

2. Penulis dianjurkan menggunakan aplikasi pengutipan standar seperti Zotero, Mendeley, atau Endnote.

3. Sistem pengutipan menggunakan body note sedangkan catatan akhir digunakan untuk menuliskan keterangan-keterangan terkait artikel. 


\section{Sistem Transliterasi}

Sistem alih aksara (transliterasi) yang digunakan merujuk pada pedoman Library of Congress (LOC).

\section{Identitas Penulis}

Penulis agar menyertakan nama lengkap penulis tanpa gelar akademik, afiliasi lembaga, serta alamat surat elektronik (email) aktif. Apabila penulis terdapat lebih dari satu orang, maka penyertaan identitas tersebut berlaku untuk penulis berikutnya.

\section{Pengiriman Naskah}

Naskah tulisan dikirimkan melalui email: jmanuskripta@gmail.com.

\section{Penerbitan Naskah}

Manuskripta merupakan jurnal ilmiah yang terbit secara elektronik dan daring (online). Penulis akan mendapatkan kiriman jurnal dalam format PDF apabila tulisannya diterbitkan. Penulis diperkenankan untuk mendapatkan jurnal dalam edisi cetak dengan menghubungi email: jmanuskripta@gmail.com. 


\section{[OThonnusk suiptor}


MANUSKRIPTA (ISSN 2252-5343) adalah jurnal ilmiah yang dikelola oleh Masyarakat Pernaskahan Nusantara (Manassa), asosiasi profesi pertama dan satu-satunya di Indonesia yang memperhatikan preservasi naskah. Jurnal ini dimaksudkan sebagai media pembahasan ilmiah dan publikasi hasil penelitian filologi, kodikologi, dan paleografi. Terbit dua kali dalam setahun. 